\title{
A FINANCEIRIZAÇÃO DA EDUCAÇÃO PRIVADA NAS PÁGINAS DE REVISTA: DISCURSOS PUBLICITÁRIOS SOBRE A UNIVERSIDADE BRASILEIRA*
}

\author{
Marcelo Maia Vinagre Mocarzel
}

\begin{abstract}
RESUMO: Neste artigo, partimos da premissa de que a educação superior privada brasileira passou por importantes transformaçóes, convertendose em objeto de consumo e, posteriormente, em ativo financeiro. Sob o viés semiótico da publicidade de instituiçóes de educação superior, fazendo uso da análise de discurso como método de pesquisa, buscamos mostrar que essa premissa é comprovada pelos anúncios das instituiçóes privadas. Como conclusóes, observamos a bancarizaçáo da publicidade, com produtos finais à venda que não são aulas ou diplomas, mas que contribuem para a oligopolização do setor educacional, por meio do fenômeno das fusóes e aquisiçôes, retratado e reforçado nos anúncios.
\end{abstract}

Palavras-chave: Educação superior. Análise de discurso. Financeirização. Publicidade.

\section{THE FINANCING OF PRIVATE EDUCATION ON THE MAGAZINE PAGES: ADVERTISING SPEECHES ON THE BRAZILIAN UNIVERSITY}

ABSTRACT: In this article, we start from the premise that the Brazilian Private Higher Education has undergone important transformations, becoming an object of consumption and, later, a financial asset. From a semiotic bias of the publicity of institutions of Higher Education, making use of Discourse Analysis as a research method, we sought to prove that this premise is proved by the announcements of the private institutions. As a conclusion, we observe a "bankization" of advertising, with final products for sale that are not classes or diplomas, and contribute to the oligopolization of the educational sector, from the phenomenon of mergers and acquisitions, portrayed and reinforced in the ads.

Keywords: Higher education. Discourse analysis. Financialization. Publicity.

\footnotetext{
*Artigo decorrente da tese de Doutorado A educação como bem de consumo: discursos publicitários sobre a universidade e a juventude no Brasil (MOCARZEL, 2016), defendida no Programa de Pós-graduação em Comunicação da Pontifícia Universidade Católica do Rio de Janeiro (PUC-Rio). Financiamento: Coordenação de Aperfeiçoamento de Pessoal de Nível Superior (Capes).

${ }^{1}$ Centro Universitário La Salle - Rio de Janeiro (RJ), Brasil. E-mail: marcelo.mocarzel@lasalle.org.br DOI: 10.1590/ES0101-73302019216625.
} 


\title{
LA FINANCIARIZACIÓN DE LA EDUCACIÓN PRIVADA EN LAS PÁGINAS DE REVISTA: DISCURSOS PUBLICITARIOS SOBRE LA UNIVERSIDAD BRASILEÑA
}

\begin{abstract}
RESUMEN: En este artículo, partimos de la premisa de que la Educación Superior privada brasileña pasó por importantes transformaciones, convirtiéndose en objeto de consumo y, posteriormente, en activo financiero. A partir de un sesgo semiótico de la publicidad de instituciones de Educación Superior, haciendo uso del Análisis de Discurso como método de investigación, buscamos mostrar que esta premisa es comprobada por los anuncios de las instituciones privadas. Como conclusiones, observamos una "bancarización" de la publicidad, con productos finales a la venta que no son clases o diplomas y contribuyen a la oligopolización del sector educativo, a partir del fenómeno de las fusiones y adquisiciones, retratado y reforzado en los anuncios.
\end{abstract}

Palabras clave: Educación superior. Análisis de discurso. Financiarización. Publicidad.

\section{Introdução}

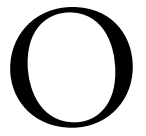

presente artigo sintetiza conclusóes apontadas em uma tese de doutorado que analisa a educaçáo superior privada brasileira e suas transformações a partir dos anos 1990. Na lógica da mercantilização, há evidências de que tal modalidade de educação se converteu em um bem de consumo. De meados dos anos 2000 em diante, a lógica de consumo intensificou-se, e a educação superior privada passou por um processo de financeirização, que ainda estamos vivendo na atualidade. Entendemos que, por meio da publicidade de instituições de educação superior, fazendo uso da análise de discurso como método de pesquisa, podemos, mais do que comprovar essa hipótese, já apontada por alguns (COSTA, 2016; CHAVES, 2010; SGUISSARDI, 2016), indicar, mediante a análise semiótica, como a publicidade acompanhou esse processo e teve papel ativo no reforço das ideias.

A análise de discurso compreende os textos, as imagens, as falas como discurso, e, portanto, repletos de sentidos, o que, para Pêcheux (2012, p. 31), indica que "todo enunciado produzido nesses espaços reflete propriedades estruturais independentes de sua enunciação" - nesse caso, a publicidade das instituições privadas de educação superior. Acreditamos que foi a publicidade, acompanhando transformaçóes mercadológicas, que começou a estimular a competição entre as instituiçóes, a estabelecer padróes de consumo da educação muito próximos aos de consumo de bens e serviços, e isso se aproxima do que Sodré (2012, p. 259) chama 
de "ideologia financista”. A educação mundial e, nesse caso específico, a educação superior brasileira compuseram um mercado com base em processos de financeirização. Ou seja, as instituiçôes educativas tornaram-se grandes corporaçôes, com capital globalizado e aplicado em ações nas bolsas de valores.

O "espírito" da modernidade diz respeito à constituição de uma sociedade baseada no trabalho útil e metódico, em valores éticos puritanos e nos ideais ascéticos (WEBER, 2004). Logo, uma sociedade que muda toda a organização social e econômica do mundo fundamentada na divisão de classes, na mais-valia, nos diferentes usos do capital (MARX, 2013). Apesar de representarem maneiras variadas de interpretar o capitalismo, essas duas visóes trazem luz para o debate sobre os caminhos que o sistema percorreu para se tornar o grande perfil hegemônico moderno. Nesse contexto, apresentamos a teoria do capital humano (TCH) como uma referência para o tipo de sociedade que se constrói pela lógica neoliberal.

A publicidade é peça-chave nessas transformaçóes operadas pelo capitalismo. De fato, os avanços tecnológicos da indústria (esteira móvel, administração científica) e dos meios de comunicaçáo e transporte (trens, avióes, rádio, televisão etc.) forjam o que conhecemos por cultura de massas (MORIN, 2009; 2011), em que o alcance simultâneo das massas é o grande objetivo. Os produtos passam a ser pensados e fabricados de modo massificado; os meios de comunicação buscam atingir o maior número de pessoas com uma única mensagem, vivendo o que Giddens (2002) tratou como alta modernidade: desencaixes das relaçóes e das instituições, tensões entre o global e o local (SANTOS, 2009) e contração do tempo e do espaço (HARVEY, 2013).

\section{Neoliberalismo, capital humano e ensino privado}

O individualismo disfarçado de liberdade, marca do neoliberalismo, acaba por aprisionar, uma vez que as exclusōes são mais profundas e um grande grupo de pessoas fica impossibilitado de gozar de certos direitos, entendidos, então, como serviços. Nesse quadro, a educação tem papel privilegiado: segundo a $\mathrm{TCH}$, ela seria a chave para o desenvolvimento pessoal e coletivo. Essa marcante teoria foi desenvolvida por um renomado economista do desenvolvimento, também laureado com o prêmio Nobel, Theodore William Schultz (1902-1998), que afirmava, entre outras coisas, que "a educação é o pressuposto do desenvolvimento econômico, bem como do desenvolvimento do indivíduo, que, ao educar-se, estaria 'valorizando' a si próprio, na mesma lógica em que se valoriza o capital” (MINTO, 2016).

Ou seja, pela visão da $\mathrm{TCH}$, a educação seria um investimento pessoal que, somado, traria desenvolvimento coletivo. Coloca-se, por essa visão, um peso redentor na educação, como motor para impulsionar o sucesso eco- 
nômico de pessoas e países. Nesse contexto, o diploma de educação superior passa a ter outro peso no mundo do trabalho, crescendo também a necessidade de especialização e formação técnica continuada, sob um paradigma tecnicista. À luz da TCH, instauram-se verdadeiras corridas por treinamentos de funcionários e cursos para ingresso e permanência no mercado de trabalho. Frigotto (2010), ao falar sobre a crise do trabalho, aponta que a perspectiva do adestramento e do treinamento no Brasil tem sido dominante desde o início da ditadura civil-militar, tendo o economicismo como eixo de sustentação teórico-ideológico.

A experiência brasileira de neoliberalismo é mais recente, porém claramente inspirada nas experiências norte-americana e britânica. No Brasil, a redemocratização marcou a abertura do país para o capital externo, ainda que antes tivéssemos algumas interferências pontuais, como o convênio entre o Ministério da Educação e a Agência dos Estados Unidos para o Desenvolvimento Internacional (USAID) ${ }^{1}$. A ditadura civil-militar brasileira, ao contrário da chilena, guardou alguns traços intervencionistas no que tange à atuação do Estado. A ideia de um Estado robusto adequava-se à lógica pseudopatriótica, de segurança nacional, que orientava os militares, dando pouca margem para privatizaçóes e investimentos externos, ainda que na educação superior tenhamos visto um grande avanço da educaçáo privada. Assim, entendemos que o neoliberalismo no Brasil só se constituiu como orientação governamental hegemônica a partir dos anos 1990, com a chegada de Fernando Collor de Mello ao poder. Apesar do curto mandato de dois anos, podemos dizer que houve uma promessa não cumprida. Se, por um lado, Collor tentou reduzir o tamanho do Estado, inclusive abrindo os portos às importaçóes; por outro, em nome do controle da economia, ele foi altamente intervencionista, tendo até mesmo confiscado a caderneta de poupança da população.

De fato, a introdução do país em uma perspectiva neoliberal só se efetivou no fim do governo Itamar Franco, com a construção do novo modelo macroeconômico para o país, o Plano Real, e nos dois governos Fernando Henrique Cardoso, quando o Brasil passou por transformaçôes significativas no que tange à administração pública. Seu auge deu-se em 1995, quando Luiz Carlos Bresser-Pereira, então ministro da Administração Federal e Reforma do Estado, lançou o Plano Diretor da Reforma do Aparelho do Estado (BRASIL, 1995). Adotou-se, nessa gestão, um modelo de administração que se assemelha ao da gestão privada, chamado de administração gerencial, voltado prioritariamente para a redução de despesas por meio de privatizaçóes, terceirizações, redução e otimização de pessoal, competitividade e orientação por resultados, entre outras medidas de cunho neoliberal, claramente inspiradas em prescriçôes de organismos multilaterais. $\mathrm{O}$ que aconteceu foi o encaminhamento do país para uma grave crise econômica, uma vez que o governo não conseguiu, após cinco anos, o equilíbrio das contas públicas pretendido. 


\section{O discurso publicitário como pedagogia para o consumo}

A existência de uma linguagem própria confere à publicidade segmentação específica no campo da comunicação. Assim como existe a linguagem cinematográfica ou a linguagem jornalística, entre outras, a linguagem publicitária é constituída de códigos, símbolos e até mitos próprios, que desenham sua forma e seu conteúdo e a diferenciam de outras. Nesse sentido, além de representar a fala, de modo ampliado a linguagem diz respeito ao dialeto de determinado grupo, bem como à expressão de caráter particular. Dessa maneira, o recorte feito à publicidade concerne à seleção e ao modo de usar as palavras, à arrumação destas, aos jargóes, às técnicas e às expressōes representadas.

Temos, portanto, uma visão baseada no estruturalismo linguístico de Ferdinand de Saussure (1857-1913), que concebeu a língua como um sistema fechado sobre si, com questóes importantes, como a preeminência da estrutura sobre a própria estrutura (SAUSSURE, 2013), formando relaçôes binárias de sentido (a não existência é o que gera a existência). Essa lógica abriu caminho para a ruptura e para os estudos analíticos do discurso. Em uma perspectiva estruturalista, discurso é "um conglomerado de palavras ou sentenças" (SAUSSURE, 2013) em que o sujeito linguístico é reprodutor e decodificador de um sistema linguístico, e o discurso confunde-se com o texto. Já para Pêcheux, discurso consiste na materialização ideológica, e a língua, num processo que perpassa as diversas esferas sociais.

Maingueneau (1997) utiliza o conceito de formação discursiva, pois a polissemia do termo discurso pode gerar confusóes conceituais. Tal termo é originário de Foucault e indica o que pode e deve ser dito, e não apenas o que é dito. Para Foucault (1996, p. 9), a produção do discurso é "controlada, selecionada, organizada e redistribuída por certo número de procedimentos que têm por função conjurar seus poderes e perigos, dominar seu acontecimento aleatório, esquivar sua pesada e temível materialidade".

Assim, o discurso desliza entre um amontoado de códigos e a formação ideológica. Neste trabalho, utilizamos o sentido de formação discursiva (MAINGUENEAU, 1997; PÊCHEUX, 2009; 2011; 2012), afastando-nos do estruturalismo e recorrendo às questóes ideológicas para analisar e interpretar os textos publicitários. Entendemos, portanto, a publicidade como um discurso, uma vez que ela carrega em si diversos sentidos, lacunas, cargas ideológicas. A publicidade quer dizer algumas coisas e não quer dizer outras; isso faz dela uma formação discursiva, entendendo que tudo o que se fala quer dizer e, ao mesmo tempo, náo quer dizer.

\section{A educação superior privada e suas transformações discursivas}

A Lei no 5.540 , aprovada em 28 de novembro de 1968, no período mais duro da ditadura civil-militar, trouxe marcas para o ensino superior que ainda 
estão presentes. Cunha (1980) traz algumas delas, presentes no relatório do grupo de trabalho do Ministério da Educação (MEC) publicado em julho de 1968, que serviu de justificativa para a aprovaçáo da lei. Em primeiro lugar, o relatório deixa claro que a expansão de vagas era desejável e necessária, mas que essa expansão não poderia retirar verbas da educação básica, que era tida como prioritária. Sendo assim, a expansão deveria ocorrer com o mínimo de gastos públicos, justificativa que balizou medidas implantadas na reforma, bem como incentivou o avanço privado da educação superior.

Uma das medidas foi a "departamentalização", que, segundo Cunha (1980, p. 242), "foi um processo de substituição das unidades acadêmicas estanques numa estrutura administrativo-pedagógica de modo a eliminar a duplicidade de trabalho". Com a organização de departamentos, disciplinas semelhantes fundiram-se e passaram a ser oferecidas a estudantes de diversos cursos, otimizando salas de aula e professores e aumentando o quantitativo de alunos por sala. Outro ponto importante da reforma foi a implantação do regime de créditos, que consiste em direcionar a matrícula por disciplinas, obrigatórias e eletivas. Do ponto de vista da racionalização econômica, essa saída possibilitava, por exemplo, que as disciplinas obrigatórias de um curso servissem como eletivas para outro, reduzindo assim o número de disciplinas e concentrando as turmas com alunos de diversas áreas.

A reportagem de capa da revista Veja de janeiro de 1970 (Figura 1) foi sobre a grande concorrência dos vestibulares, recém-unificados, trazendo dicas para os estudantes obterem sucesso nos estudos e na vida profissional. Ainda, a reportagem fez uma crítica profunda a universidades que ainda não haviam se adequado à reforma universitária e que continuavam a oferecer cursos com baixa demanda do mercado. Em um dos trechos, o reitor da Universidade Federal do Rio Grande do Sul lamentou não ter podido seguir as orientações traçadas pela reforma de só abrir vagas em áreas consideradas prioritárias para o desenvolvimento. Isso demonstra, em nossa percepção, que a reforma abriu as portas para que a mídia e a sociedade estabelecessem relaçóes diretas entre o ensino universitário e o desenvolvimento econômico do país.

Na peça publicitária seguinte (Figura 2), da Caixa Econômica Federal de 1977, mesmo nove anos após a edição da reforma universitária, focou-se na construção do jovem como sujeito do futuro - "futuro doutor", porém o mais importante é que o anúncio tratava diretamente de um dos objetos centrais de análise deste artigo: a relação entre educação superior e financiamento.

O anúncio enaltecia o Programa de Crédito Educativo, criado pelo MEC em 1976. Foi o primeiro programa público de financiamento da educação superior, abrindo vagas em instituiçôes privadas para alunos sem recursos para pagar. Muitas universidades cresceram com esse financiamento público, que foi encerrado em 1991, graças à hiperinflação e ao contexto neoliberal que se instalava, e que foi retomado em 1999, com o nome de Fundo de Financiamento Estudantil (Fies). 


\section{Figura 1}

Capa da revista Veja de 1970: "Vestibular: a difícil competição".

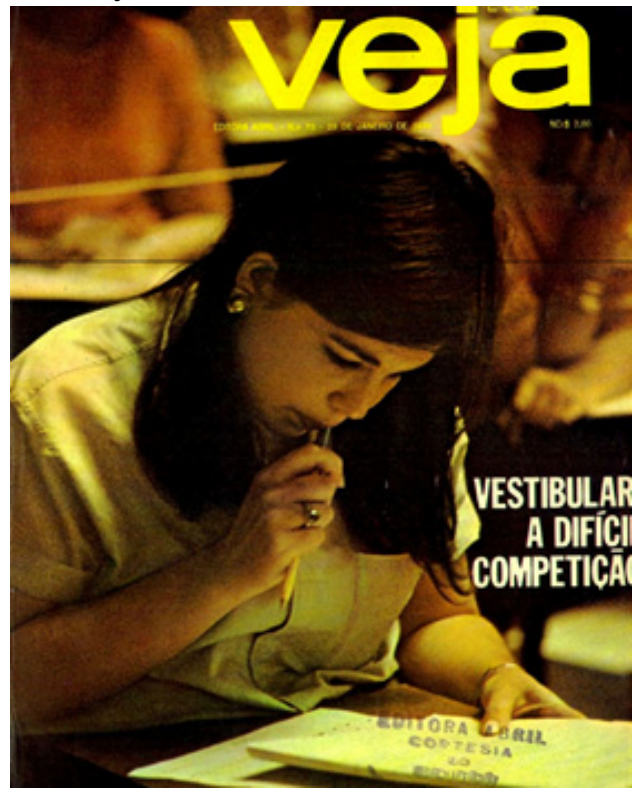

Fonte: Veja, n. 73, 28 jan. 1970.

\section{Figura 2}

Anúncio da Caixa Econômica Federal, 1977.

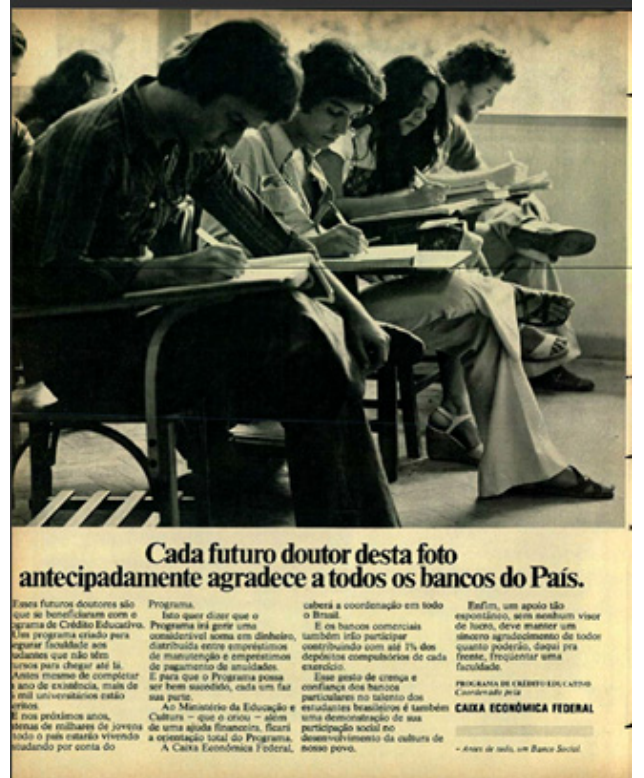

Fonte: Veja, n. 438, 26 jan. 1977. 
Na peça, podemos ver a materialização da TCH quando da frase: "Esse gesto de crença e confiança dos bancos particulares no talento dos estudantes brasileiros é também uma demonstração de sua participação social no desenvolvimento da cultura de nosso povo". Assim, educação e desenvolvimento estáo diretamente associados, tendo como fiadores os bancos (privados), que investem em talentos futuros. Essa rápida análise de discursos publicitários e jornalísticos é apenas uma breve ilustração do que estamos buscando demonstrar com base no aporte teórico apresentado.

Um dado interessante que merece destaque é que, por lei, até 1997, nenhum estabelecimento educacional brasileiro de nível superior poderia ser comercial. O Decreto no 2.306, de 19 de agosto de 1997, assinado pelo entáo presidente Fernando Henrique Cardoso, foi o primeiro instrumento legal a autorizar que as instituições de ensino superior "poderão assumir qualquer das formas admitidas em direito, de natureza civil ou comercial" (BRASIL, 1997).

Antes disso, todas as instituiçóes eram constituídas de mantenedoras sem fins lucrativos. Na prática, sabemos que isso não funcionou como a lei regia. Diversas instituiçōes (e, incrivelmente, isso persiste até os dias de hoje em alguns casos) eram empresas disfarçadas de entidades sem fins lucrativos, pagando salários exorbitantes aos seus mantenedores (clara camuflagem para a distribuição de lucros) e usadas como pessoa jurídica adquirente de bens pessoais (imóveis, veículos etc.) para seus proprietários.

Vivemos agora o ápice desse mercado. No ano de 2016, os oito maiores grupos educacionais do país detinham mais de $27 \%$ das matrículas totais. Esse percentual equivale a dois milhóes e 100 mil alunos. A rede pública (federais, estaduais e municipais), que passou na última década por intensa expansão, por meio do programa Reestruturação e Expansão das Universidades Federais (Reuni) ${ }^{2}$, contava no mesmo ano com $25 \%$ das matrículas (FUNDAÇÃO GETULIO VARGAS, 2016). Em 2016, articulou-se a fusão dos grupos Kroton e Estácio, que, se tivesse sido efetivada, aumentaria ainda mais a concentração, respondendo, como instituição única, por mais de um milhão e 300 mil matrículas, consolidando-se como o maior grupo educacional do mundo.

Esses conglomerados educacionais são formados por empresas brasileiras de capital aberto (Anhanguera, Ânima Educação, Estácio, Kroton e Ser Educacional) e internacionais (DeVry e Laureate), além do grupo Universidade Paulista (UNIP). Apenas esses oito grupos possuíam, em 2014, de acordo com dados do censo do ensino superior utilizados na pesquisa, 219 instituiçóes de ensino em um universo de 2.069 faculdades particulares. A rede pública, com 298 unidades, teve alta de 19,3\% no corpo discente, passando de 1,64 milhão para 1,96 milhão no mesmo período (FUNDAÇÃO GETULIO VARGAS, 2016). 
Essa marcha triunfante das empresas do setor educacional do mercado, que se inicia em 2007, quando da abertura de capital das primeiras dentre elas - Anhanguera Educacional, Estácio Participaçóes, Kroton (Pitágoras) e SEB (Sistema Educacional Brasileiro; hoje parte da Estácio) - e se consolida diante da baixa concorrência num mercado aberto e pouco explorado (taxa líquida 29 de apenas cerca de $10 \%$ e da clara disposiçáo do governo de turno de garantir-lhes os adimplentes bônus do fundo público Programa Universidade para Todos [ProUni] e Fies - somente sofrerá um freio quando são editadas as Portarias Normativas MEC n. 21 e 23 32, de 29/12/2014 (SGUISSARDI, 2016, p. 19).

De agosto de 2012 a agosto de 2014, o setor educacional na bolsa de valores, formado por apenas 15 empresas, representava o mais lucrativo do mercado de capitais do Brasil. Como comparativo, nesse período de valorizaçáo de todas as empresas (cerca de 350), o Índice Ibovespa era, em média, de 4\%, enquanto as açóes da Kroton atingiram valorizaçáo de $314 \%$ e as da Estácio de 240\% (SGUISSARDI, 2016). Assim, deu-se a expansão privado-mercantil da educação superior no Brasil, por meio de intensos processos de mercantilizaçáo.

Mercantilização, segundo o Dicionário Houaiss (2001), é o ato de tornar-se mercadoria, ou seja, indica um processo de transformação de algo, que antes só tinha valor de uso para algo com valor de troca. Marx (2013, p. 113) afirma que "a mercadoria é, antes de tudo, um objeto externo, uma coisa que, por meio de suas propriedades, satisfaz necessidades humanas de um tipo qualquer". Segundo ele, é a utilidade de uma coisa que faz com que ela tenha valor de uso, que se efetiva em seu consumo. "Os valores de uso formam o conteúdo material da riqueza, qualquer que seja a forma social desta” (MARX, 2013, p. 114).

Fugindo de comparaçóes e pensando em um novo contexto, mais restrito e específico, indicamos que esse mesmo processo ocorreu com o ensino superior, desde a mudança paradigmática trazida pelo Decreto no 2.306 em 1997. Não que antes a educação universitária fosse algo sem valor mercadológico, ou que os proprietários de instituiçôes náo visassem ao lucro ou pudessem vender estudos e diplomas. A realidade, como já citamos, mostra que sempre existiu um mercado do ensino superior no momento em que ele foi aberto à iniciativa privada, ainda que sem fins lucrativos, mas a diferença é que se tratava de um mercado paralelo, clandestino, camuflado por um aparato legal que impedia a sua exibiçấo. $\mathrm{O}$ texto do decreto era bem claro quanto à atividade mercantil:

As instituiçóes privadas de ensino, classificadas como particulares em sentido estrito, com finalidade lucrativa, ainda que de natureza civil, quando mantidas e administradas por pessoa física, ficam submetidas ao regime da legislação mercantil, quanto aos encargos fiscais, parafiscais e trabalhistas, como se comerciais fossem, equiparados seus mantenedores e administradores ao comerciante em nome individual (BRASIL, 1997, grifos nossos). 
Com a liberação para a constituição de empresas, tudo isso mudou. Iniciou-se um processo de compra e venda de instituiçôes ancorado por uma publicidade arrojada, que começou a pensar no ensino superior como uma possibilidade ampla; afinal, a lógica do mercado é alcançar todos os consumidores possíveis. A relaçáo aluno e saber, que se constituía nas instituiçóes públicas e acabava refletindo-se na maioria das privadas, foi substituída por uma relação comercial, de cliente e fornecedor, envolvendo também os docentes. De lá para cá, esse quadro intensificou-se e agravou-se, chegando ao modelo de financeirização.

Adotamos a definição de Krippner (2005, p. 14), que por financeirização entende "um padrão de acumulação no qual a produção do lucro se dá crescentemente através de canais financeiros ao invés de ser pela via do comércio e da produçáo de commodities". Ainda segundo a autora, trata-se de um movimento global alavancado pelo capitalismo financeiro decorrente dos investimentos em açóes. Marx já havia citado o capital financeiro como um processo de automatizaçâo dos lucros do capital comercial.

O dinheiro efetua alguns movimentos puramente técnicos no processo de circulação do capital industrial e do capital comercial, como por exemplo, pagamentos, recebimentos de dinheiro, operaçóes de compensaçáo etc. Quando estes movimentos se tornam uma função autônoma de um capital particular que os executa como operaçóes peculiares e nada além disso, transformam esse capital em capital financeiro (MARX, 1985, p. 363).

Ou seja, a financeirização é o afastamento do negócio em si e a simultânea aproximaçáo da especulaçáo como forma de obtenção de lucros. Acreditamos que é por esse processo que o ensino superior passa, desde 2007, quando a Anhanguera abriu seu capital na bolsa de valores de São Paulo. O mercado universitário transformou-se em algo diferente da prestação de serviços educacionais. Até mesmo recentemente, após a retração do Fies por parte do governo, as próprias instituiçóes tornaram-se entidades financeiras (com estrutura própria ou convênio), possibilitando o pagamento parcelado após a conclusão dos cursos. Dessa maneira, as instituiçóes de ensino que fazem parte dos oligopólios educacionais (CHAVES, 2010) se assemelham hoje a bancos e financeiras, gerando receitas por intermédio de empréstimos, e não apenas do negócio em si, a ponto de hoje ser lucrativo para a empresa o aluno parar de pagar, uma vez que os juros incidentes elevam exponencialmente os valores devidos.

O empresariamento da educação superior e a formação de um mercado e sua posterior financeirização mostram que estamos diante de um processo racionalista de transformação da educaçáo. Do ponto de vista da comunicação, a publicidade constitui-se como meio para divulgaçáo positiva dessas mudanças, na medida em que parte considerável das camadas médias e até das classes populares enxerga esse movimento, com certa lógica, como uma valorosa expansão do acesso 
a diplomas universitários. A universidade, enquanto instituição com identidade própria, vai se apagando, e começa a surgir um novo tipo de negócio cujo compromisso secundário é a formaçáo, e o primário, a lucratividade.

Assim, abre-se caminho para o mercado (mesmo via governo, com políticas de financiamento às instituiçôes privadas e com a transferência de profissionais para ganharem melhores rendimentos), fazendo com que a demanda seja suprida de forma híbrida, e não por meio do aparelho do Estado. Um mercado "selvagem e desregulado", que reforça a "descapitalização e desestruturação" do ensino público e opta pela "mercadorização da universidade" (SANTOS, 2004, p. 10). Segundo o autor, o que está em curso hoje é uma globalização neoliberal da universidade. Santos (2004) ainda aponta que tanto o desinvestimento na educação superior pública quanto o avanço dos conglomerados privados são duas faces da mesma moeda, considerando que uma depende da outra para a transmutação do perfil do bem público que a universidade vem produzindo.

Para exemplificar, selecionamos a Veja, por se tratar da mais popular revista semanal do país, publicada ininterruptamente desde 1968. De acordo com Nascimento (2002), o periódico detinha, em 1997, 79\% do total da circulaçáo das revistas semanais. E é esse ano que usamos como corte temporal para início das análises. Foram cerca de 1.090 ediçóes analisadas, em um total aproximado de 140 mil páginas, ao longo de mais de quatro meses. Em muitas das ediçóes, não foram encontrados anúncios de instituiçôes de ensino privado. A maior parte dos anúncios localizados concentra-se nos anos mais recentes, o que já é indício de confirmação da hipótese: o aspecto comercial das instituiçôes está sofisticando-se.

Das centenas de anúncios possíveis de serem analisados, selecionamos três para integrarem o corpus deste artigo, tendo como unidade de análise as sequências discursivas $(\mathrm{SD})$ selecionadas. Como o marco temporal é o decreto de 1997, selecionamos anúncios a partir desse período. O primeiro é um anúncio clássico (Figura 3), de uma pequena instituição de ensino sem fins lucrativos, com todos os elementos que são esperados: jovens, profissionais em formação, destaque à qualidade do ensino etc. O anúncio, veiculado em 1998, é da Universidade José do Rosário Vellano (Unifenas), instituição que se mantém até hoje como sem fins lucrativos, segundo o e-Mec ${ }^{3}$, ainda que uma rápida análise na história institucional demonstre que a instituição pertença a um grupo familiar, sendo a reitora atual descendente direta do fundador ${ }^{4}$.

$\mathrm{Na}$ SD 1, "UNIFENAS/Universidade de Alfenas: Grandes profissionais conhecem a força desse nome", encontra-se a chamada do anúncio, que se refere ao nome da instituição. Nesse caso, o substantivo nome está acompanhado de outro: força. O discurso não diz respeito a um nome, mas a uma marca. Para Carvalho (2007, p. 37), a marca é um instrumento de categorização do real, pois "constrói a passagem do realismo da matéria (nome comum) ao simbolismo (nome próprio)". Juntos, eles compóem uma locução que remete à tradição, ao 
reconhecimento, à credibilidade. A marca é algo típico do mercado publicitário, o que mostra uma intençâao de diferenciação em relação a outras.

$\mathrm{O}$ enunciado concerne a grandes profissionais, que, de acordo com o texto, endossam a qualidade acadêmica da universidade. Esta é uma característica comum a muitas peças publicitárias, a tentativa de atribuir uma aprovação exógena ao produto ou serviço. Nessa perspectiva, o que é anunciado ganha credibilidade, uma vez que quem ressalta a qualidade é alguém de fora, sem compromissos com a marca, ainda que esse alguém seja oculto, sintaticamente, pela indeterminação do sujeito.

No fim da página, há uma pequena assinatura da marca (SD 2: "26 anos fazendo o profissional do século 21"), o que é tratado por Figueiredo (2007, p. 26) como "peroraçáo". Trata-se de uma informação final em que se busca maior relevância na cabeça do consumidor. A Unifenas escolheu usar uma frase com recursos imagéticos, ressaltando seu tempo de mercado. A tradição novamente é ressaltada com a expressão 26 anos. $\mathrm{O}$ uso de números estabelece um paralelo entre o tempo de vida institucional e o século 21, que se aproximava (o anúncio é de 1998). Naquele momento, o século 21 era sinônimo de futuro, de modernidade, de atualização. No fim, a mensagem que buscou ser passada era a de que a instituição alia tradição e modernidade, um roteiro bastante comum em anúncios de instituiçôes educativas.

\section{Figura 3}

Universidade José do Rosário Vellano (Unifenas), 1998.

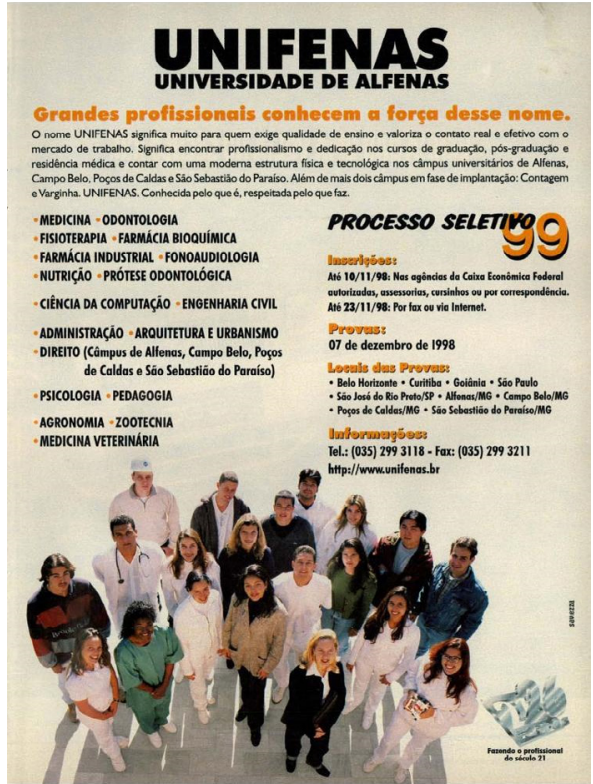

Fonte: Veja, n. 1.570, p. 56, 28 out. 1998. 
A cultura de massas vive do estabelecimento de uma receita padrão, a ser seguida e reproduzida, como diria Morin (2011). Assim, muitos anúncios parecem-se, utilizam as mesmas linhas argumentativas, as mesmas retóricas, as mesmas composições textual-imagéticas, há uma técnica bem especificada para a produção na indústria cultural. Os produtos da cultura de massas operam por intermédio de dois pares antiéticos: "burocracia-invenção, padrão-individualidade" (MORIN, 2011, p. 16).

$\mathrm{O}$ anúncio da Unifenas representa, portanto, o primeiro momento da recente expansão do ensino superior, pós-decreto, em que a fórmula clássica da propaganda girava em torno das promessas ligadas à qualidade de ensino e das promissoras perspectivas profissionais em nível local. No anúncio seguinte, o que vemos é outra lógica, já voltada para a internacionalização do capital e para o reforço positivo de outros valores, marcando um segundo momento.

A seguir, há a peça publicitária da associação entre a Universidade Veiga de Almeida (UVA) e a American University System (Figura 4), um grupo internacional que gere diversas universidades no continente americano, veiculada em 2011, anos após a abertura do capital das primeiras instituiçôes brasileiras na bolsa de valores, que se deu em 2007. As sequências discursivas destacadas são as seguintes:

Figura 4

UVA, 2011.

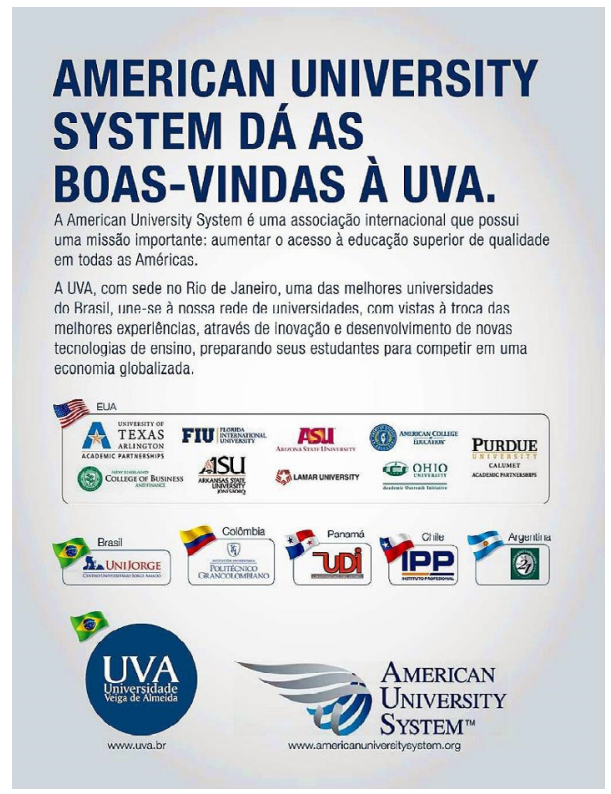

Fonte: Veja, no 2.201, p. 44, 26 jan. 2011. 
- SD 3: "American University System dá as boas-vindas à UVA";

- $\quad$ SD 4: "A UVA, com sede no Rio de Janeiro, uma das melhores universidades do Brasil, une-se à nossa rede de universidades, com vistas à troca das melhores experiências, através de inovação e desenvolvimento de novas tecnologias de ensino, preparando seus estudantes para competir em uma economia globalizada".

O título da peça publicitária é feito com fonte em tamanho grande, trazendo para si o foco do olhar do leitor. A escolha do sujeito do período causa uma pequena confusão: se o sujeito da frase é American University System, seria ele o anunciante, e não a UVA? Assim, temos um discurso de boas-vindas à instituição brasileira, que se juntou a um grupo de instituiçôes internacionais, e não o contrário: a UVA trazendo para o Brasil uma associação internacional. O discurso fala em preparar seus estudantes para competir em uma economia globalizada.

Como já destacamos em Giddens (2002), a globalizaçâo depende de mecanismos de desencaixe das instituiçóes. Assim, rompem-se fronteiras e a própria lógica temporal. A associação internacional de instituições traz um pouco desse desencaixe, ainda que implique algum tipo de conformação: descartam-se aspectos culturais próprios do processo educacional em nome de uma aliança econômica, travestida de um caráter de aprimoramento. Carvalho (2013) aponta que a internacionalização é um dos aspectos da conversão da ideologia financista:

O fenômeno recente que não pode ser ignorado é o movimento multifacetado de financeirização, oligopolizaçâa e internacionalização da educação superior brasileira. Ainda que o processo de mercantilização restrinja-se a poucas instituiçôes de educação superior mercantis, esses estabelecimentos representam um número expressivo de matrículas e cursos (CARVALHO, 2013, p. 773).

Por fim, temos o anúncio da Figura 5, da Anhanguera, que coroa o debate e a própria hipótese defendida no artigo. Publicado em 9 de dezembro de 2015, no auge da crise econômica que hoje ainda atinge o país, seu conceito era focado em aspectos financeiros.

- SD 5: "Sem crise";

- SD 6: "Com parcelamento garantido pague 30\% da mensalidade sem juros*”.

A SD 5 é o que poderíamos classificar como ironia. O enunciado sem crise indica o oposto: que o país vive uma intensa crise. Assim, a instituição anunciante tenta se posicionar na contramão daquilo que Morin (2009) e outros tratam como zeitgeist, o espírito do tempo, o clima sentido pela sociedade em deter- 
minado momento. $\mathrm{O}$ foco do anúncio são as condiçóes de pagamento facilitadas, que possibilitariam que o aluno não sentisse a crise.

Cabe apontar que na SD 6 se passam a vender serviços financeiros, na medida em que o grande diferencial é o pagamento de $30 \%$ da mensalidade sem juros e o parcelamento garantido. O silêncio, novamente, fala mais do que o que foi dito. Para os outros $70 \%$, incidem juros. Há um perigoso símbolo gráfico, o asterisco, que indica que nada é tâo simples quanto parece, levando a explicaçóes mais meticulosas das condiçóes comerciais em letras pequenas e em texto pouco propagandístico.

Acreditamos que a cobrança de juros para atrasos é uma prática legal, tendo em vista que a instituição precisa garantir a adimplência para pagar suas contas e expandir. Mas o que ocorre, a partir desse momento, é que os grandes grupos enxergam um novo nicho de atuação: os serviços financeiros. Vale (2017) faz uma crítica a essa transformação de perfil das grandes instituições de ensino superior com base em um famoso slogan de uma extinta rede de bancos: "Nem parece banco". Cada vez mais as grandes redes universitárias se preocupam menos com a educação e mais com os resultados financeiros, que devem ser prestados aos acionistas. Cada vez mais serviços de endividamento são oferecidos, e, hoje, a inadimplência deixou de ser um problema considerando que o endividamento do aluno gera um total de recebíveis muito maior, por conta dos juros.

\section{Figura 5}

Anhanguera, 2015.

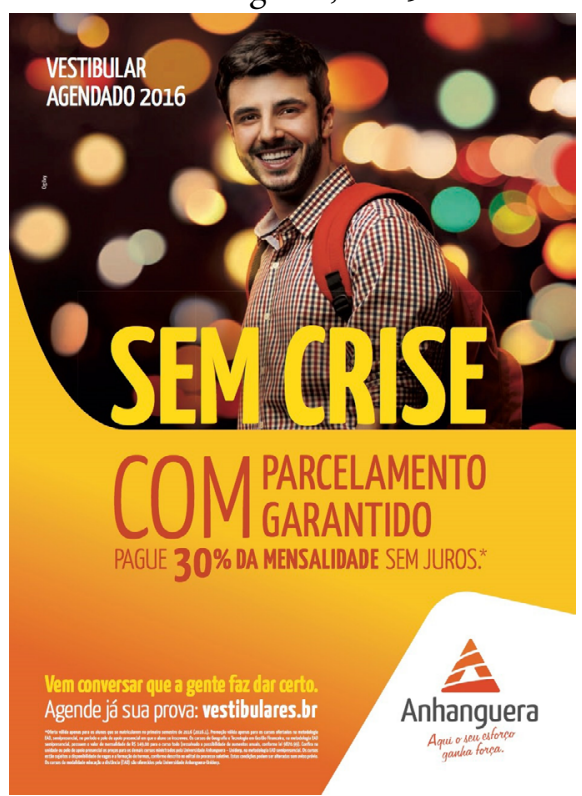

Fonte: Veja, n. 2.455, p. 16, 9 dez. 2015. 
A imagem do jovem feliz, de mochila nas costas, mascara uma realidade que ainda é inicial no Brasil, porém que em países de capitalismo avançado já é um anúncio de nova crise: o endividamento estudantil. Como exemplo, as bolsas contraídas nos Estados Unidos representam hoje um endividamento coletivo de mais de 1 trilháo de dólares, quase do tamanho da bolha hipotecária da crise dos subprimes.

\section{Considerações finais}

Com o agravamento da crise econômica, mas também política e social, as peças publicitárias das grandes instituiçóes de ensino passaram a ter, de maneira geral, uma nova roupagem. Acirrou-se a competição por alunos, facilitando as formas de pagamento e financiamento. Com a crise, programas como o Fies e o ProUni sofreram cortes, e muitas instituiçôes altamente dependentes passaram por fortes revezes. Por isso, iniciou-se, nesse cenário, uma disputa por novos alunos com um diferencial: as condiçôes de pagamento. Instituiçôes criaram linhas próprias de financiamento, independentes dos programas do governo federal, e surgiram até mesmo empresas especializadas em crédito universitário.

Chegaram ao mercado empresas especializadas em crédito estudantil, financeiras que atuam de forma independente e concedem empréstimos, alegando, de maneira enganosa, não cobrarem juros. Como conclusôes de pesquisa, gostaríamos de destacar dois pontos que sobressaíram em relação aos demais. Há a bancarização da publicidade, com produtos finais à venda que não são aulas, diplomas, formaçóes. As instituiçóes privadas de educação superior transformaram-se em financeiras, que têm no crédito educacional seu principal ativo. Ou seja, o ensino importa menos que o retorno financeiro, quando deveriam caminhar juntos. Por fim, identificamos a oligopolização do setor educacional, em que só restarão poucos grupos, por intermédio do fenômeno das fusōes e aquisições. E isso caminha também para a educação básica, no intuito de expandir mercados com a saturação em nível superior, com a desaceleração do financiamento público.

Não estamos aqui para negar a importância da expansão da educação superior, tampouco para atacar instituiçóes privadas comprometidas com a qualidade. Somos cientes do serviço prestado por instituiçóes privadas, em todos os níveis, para o desenvolvimento humano, cidadão e acadêmico de seus alunos. O que criticamos é a transformação dos valores de um setor tão importante para o país e para as pessoas. Uma transformaçáo insustentável, baseada em premissas controversas que, em nome de resultados financeiros, abrem mão de suas razóes de existir. Um exemplo disso é que muitas dessas instituições não costumam contratar professores doutores, pois estes são mais caros; contratam professores de menor titulação para reduzir os custos da folha de pagamento. Além disso, há o aumento do número de alunos por professor, a redução de oportunidades de pesquisa e extensão, tudo isso com base na eficiência financeira, atacando diretamente o trabalho docente. 
A educação passa a ser vista não mais como um direito, não mais como um caminho para a emancipação, para a formação humana e profissional, mas como algo que se consome, algo descartável, uma lógica simbólica controversa. Consome-se a educação para dar resposta à família, ao trabalho, à sociedade, e perde-se o elemento vital desse processo: o conhecimento. Exportam-se os mais brilhantes cérebros; as instituiçôes públicas de educação superior e algumas confessionais e filantrópicas resistem como ilhas de excelência em meio a um oceano de instituiçóes massificadoras. A cultura de massas requer uma educação de massas. E é isso que as grandes instituiçóes, em maior ou menor grau, estão fornecendo. Nas palavras de Aguiar (2016, p. 125), "megagrupos financeiros que exploram a educação superior como uma commodity cuja principal função é gerar dividendos aos acionistas".

\section{Notas}

1. Criada em 1961, a USAID é um órgão do governo dos Estados Unidos encarregado de prestar assistência externa de caráter civil. Trata-se de um organismo independente, embora siga as diretrizes estratégicas do Departamento de Estado dos Estados Unidos.

2. Foi criado em 2007, visando modernizar as universidades federais existentes, criar novos cursos e abrir novas instituiçóes em áreas estratégicas. Se até o ano de 2002 o Brasil contava com 43 instituiçôes de ensino superior federais espalhadas em 148 campi, em 2016 passaram a ser 63 (com o total de 321 campi) e aumento de $100 \%$ no número de matrículas, chegando ao patamar de um milhão e 100 mil alunos em 2016.

3. Disponível em: <http://emec.mec.gov.br>. Acesso em: 17 jul. 2017.

4. Disponível em: <https://www.unifenas.br/institucional.asp>. Acesso em: 17 jul. 2017.

\section{Referências}

AGUIAR, V. Um balanço das políticas do governo Lula para a educaçáo superior: continuidade e ruptura. Revista de Sociologia e Política, v. 24, n. 57, p. 113-126, 2016. http://dx.doi.org/10.1590/1678-987316245708

BRASIL. Decreto no 2.306, de 19 de agosto de 1997. Brasília: Presidência da República, 1997.

BRASIL. Plano diretor da reforma do aparelho do estado. Brasília: Presidência da República, 1995.

CARVALHO, C. H. A. de. A mercantilização da educação superior brasileira e as estratégias de mercado das instituiçôes lucrativas. Revista Brasileira de Educação, v. 18, n. 54, p. 761776, jul.-set. 2013. http://dx.doi.org/10.1590/S1413-24782013000300013

CARVAlHO, N. de. Publicidade: a linguagem da sedução. São Paulo: Ática, 2007. 
CHAVES, V. L. J. Expansão da privatização/mercantilização do ensino superior brasileiro: a formação dos oligopólios. Educaçáo e Sociedade, Campinas, v. 31, n. 111, p. 481-500, abr.-jun. 2010. http://dx.doi.org/10.1590/S0101-73302010000200010

COSTA, F. L. O. Financeirizaçáo do capital no ensino superior privado com fins lucrativos no Brasil (2007-2012). Tese (Doutorado em Educação) - Faculdade de Educação da Universidade de São Paulo, São Paulo, 2016.

CUNHA, L. A. Educaçáo e desenvolvimento social no Brasil. Rio de Janeiro: Francisco Alves, 1980.

FIGUEIREDO, C. A última impressão é a que fica. São Paulo: Thomsom, 2007.

FOUCAULT, M. A ordem do discurso: aula inaugural no Collège de France, pronunciada em 2 de dezembro de 1970. Sáo Paulo: Loyola, 1996.

FRIGOTTO, G. Educação e formação humana: ajuste neoconservador e alternativa democrática. In: GENTILI, P.; SILVA, T. T. Neoliberalismo, qualidade total e educação: visões críticas. Petrópolis: Vozes, 2010.

FUNDAÇÃO GETULIO VARGAS. Participação dos grupos educacionais no ensino do Direito. São Paulo: Observatório do Ensino do Direito (OED), 2016.

GIDDENS, A. Modernidade e identidade. Rio de Janeiro: Zahar, 2002.

HARVEY, D. Condição pós-moderna. São Paulo: Edições Loyola, 2013.

HOUAISS, Antônio. Dicionário Houaiss da Língua Portuguesa. Rio de Janeiro: Objetiva, 2001.

KRIPPNER, G. The financialization of the American economy. Socio-Economic Review, v. 3, n. 2, p. 173-208, 2005. http://dx.doi.org/10.1093/SER/mwi008

MAINGUENEAU, D. Novas tendências em análise do discurso. Campinas: Pontes; Editora da Universidade Estadual de Campinas, 1997.

MARX, K. O capital: crítica da economia política. Livro I: o processo de produção do capital. São Paulo: Boitempo, 2013.

MARX, K. O capital: crítica da economia política. Livro III: o processo de produção do capital. São Paulo: Boitempo, 1985.

MINTO, L. W. Teoria do capital humano. Glossário do Grupo de Estudos e Pesquisas História, Sociedade e Educaçáo no Brasil. Disponível em: $\leq$ http://www.histedbr. fe.unicamp.br/navegando/glossario/verb c teoria \%20do capital humano.htm>. Acesso em: 27 jan. 2016.

MOCARZEL, M. A educação como bem de consumo: discursos publicitários sobre a universidade e a juventude no Brasil. Tese (Doutorado em Comunicação) - Pontifícia Universidade Católica do Rio de Janeiro, Rio de Janeiro, 2016.

MORIN, E. Cultura de massas no século XX: o espírito do tempo 1: neurose. Rio de Janeiro: Forense Universitária, 2011.

MORIN, E. Cultura de massas no século XX: o espírito do tempo 2: necrose. Rio de Janeiro: Forense Universitária, 2009. 
NASCIMENTO, Patrícia Ceolin. Jornalismo em revistas no Brasil: um estudo das construçôes discursivas em Veja e Manchete. São Paulo: Annablume, 2002.

PÊCHEUX, M. Análise de discurso: Michel Pêcheux. Campinas: Pontes, 2011.

PÊCHEUX, M. O discurso: estrutura ou acontecimento. Campinas: Pontes, 2012.

PÊCHEUX, M. Semântica e discurso: uma crítica à afirmação do óbvio. Campinas: Editora da Unicamp, 2009.

SANTOS, B. de S. A universidade no século XXI: para uma reforma democrática e emancipatória da universidade. São Paulo: Cortez, 2004.

SANTOS, B. de S. Democratizar a democracia: os caminhos para a democracia participativa. Rio de Janeiro: Civilização Brasileira, 2009.

SAUSSURE, F. de. Curso de linguística geral. São Paulo: Cultrix, 2013.

SGUISSARDI, V. Educação superior no Brasil - refém do mercado ou quando a face privado-mercantil se sobrepóe à face pública do Estado. In: CHAVES, V. L. J.; MAUÉS, O. C.; HAGE, S. M. (orgs.). Expansáo privado-mercantil da educaçáo superior no Brasil. Campinas: Mercado das Letras, 2016.

SODRÉ, M. Reinventando a educação: diversidade, descolonização e redes. Petrópolis: Vozes, 2012.

VALE, A. A. do. "Nem parece banco": as faces da financeirização da Educação Superior no Brasil. Anais do Encontro Internacional e Nacional de Política Social, v. 1, n. 1, 2017. WEBER, M. A ética protestante e o “espírito” do capitalismo. São Paulo: Companhia das Letras, 2004.

\section{SOBRE O AUTOR}

Marcelo Maia Vinagre Mocarzel é Doutor em Comunicação pela PUC-Rio e Mestre em Educação pela UFF, onde atualmente realiza estágio pós-doutoral em Educação. É professor do Unilasalle-RJ e pesquisador do Nugeppe/UFF e JuX/PUC-Rio.

Recebido em 19 de novembro de 2018.

Aceito em 29 de maio de 2019. 